\title{
Pengembangan alat pembelajaran GeoKlik untuk pembelajaran geometri
}

\author{
Aan Hendroanto ${ }^{1^{*}}$, Harina Fitriyani ${ }^{1}$ \\ ${ }^{1}$ Program Studi Pendidikan Matematika, Universitas Ahmad Dahlan, Indonesia \\ *Corresponding Author. E-mail: aan.hendroanto@pmat.uad.ac.id
}

\begin{tabular}{ll}
\hline \multicolumn{1}{c}{ ARTICLE INFO } & \multicolumn{1}{c}{ ABSTRACT } \\
\hline Article History: & Objek matematika sebagian besar bersifat abstrak dan sulit untuk dibayangkan sehingga \\
Received: 21 Nov. 2018 & banyak siswa yang kesulitan untuk memahaminya. Salah satu solusi untuk membantu siswa \\
Revised: 6 May 2019 & dalam hal ini yaitu dengan menggunakan alat-alat Euclid seperti penggaris, jangka, dan busur \\
Accepted: 28 June 2019 & untuk menggambar objek geometri di papan tulis atau whiteboard. Namun, penggunaan alat- \\
& alat Euclid untuk menggambar terkadang tidak maksimal dikarenakan kurang efisien dan \\
& merepotkan. Penelitian ini bertujuan untuk menghasilkan alat yang dinamakan GeoKlik untuk \\
Keywords: & mendukung kegiatan pembelajaran geometri. GeoKlik merupakan penggabungan alat-alat \\
Pengembangan, & menggambar geometri Euclid yang didesain agar penggunaannya lebih fleksibel dan mudah \\
Alat pembelajaran, & sehingga guru maupun siswa dapat menggunakannya dalam proses belajar mengajar tanpa \\
GeoKlik, & kesulitan. Pengembangan pada penelitian ini menggunakan model pengembangan 4D yang \\
Geometri, & terdiri dari 4 tahap pengembangan yaitu define, design, development, dan dissemination. \\
Development, & Penelitian pengembangan ini dilakukan di Program Studi Pendidikan Matematika FKIP UAD. \\
Learning tool. & Analisis data dalam penelitian ini menggunakan metode deskriptif kualitatif. Namun demikian, \\
Geometry. & analisis data tetap melibatkan data kuantitatif dan perhitungan statistika sederhana. Berdasar- \\
& kan hasil validasi ahli media, alat GeoKlik mendapat penilaian sangat baik dari ahli media \\
& dengan nilai rata-rata 4,79. Dari segi aspek desain, GeoKlik mendapat nilai rata-rata sebesar \\
& 4,78 dengan kategori sangat baik. Aspek keefektifan GeoKlikjuga memperoleh skor sangat baik \\
& dengan nilai rata-rata 4,81. Sedangkan untuk aspek kepraktisan, GeoKlik mendapat nilai rata- \\
& rata 4,75 dengan kategori sangat baik. Respon yang diberikan guru dan siswa terhadap alat \\
& GeoKlik ini juga sangat positif dengan nilai rata-rata keseluruhan yaitu 4,79 untuk respon guru, \\
& sedangkan nilai respon rata-rata siswa yaitu sebesar 4,51. \\
\hline &
\end{tabular}

Mathematical objects are mostly abstract and difficult to imagine so that many students have difficulty understanding them. One solution to help students, in this case, is by using Euclid tools such as rulers, rows, and arcs to draw geometric objects on the board or whiteboard. However, the use of Euclid tools for drawing is sometimes not optimal because it is less efficient and troublesome. This study aims to produce a tool called Geoklik to support geometry learning activities. GeoKlik is a combination of Euclid's geometric drawing tools designed so that its use is more flexible and easy so that teachers and students can use it in the learning process without difficulty. The development of this study used a 4D development model consisting of 4 stages of development, namely define, design, development, and dissemination. This development research was conducted at the Mathematics Education Study Program FKIP UAD. Data analysis in this research used the descriptive qualitative method. However, data analysis still involved quantitative data and simple statistical calculations. Based on the results of the media expert validation, the GeoKlik tool was very well rated by media experts with an average value of 4.79 . In terms of design aspects, GeoKlik scored an average of 4.78 with very good categories. The aspect of GeoKlik effectiveness also scored very well with an average value of 4.81 . Whereas for the practicality aspect, GeoKlik got an average value of 4.75 with a very good category. The response given by the teacher and students to the GeoKlik tool was also very positive with an overall mean value of 4.79 for the teacher's response, while the average response value of the student was 4.51.

This is an open access article under the CC-BY-SA license (cc) (i) (2)

How to Cite:

Hendroanto, A., \& Fitriyani, H. (2019). Pengembangan alat pembelajaran GeoKlik untuk pembelajaran geometri. PYTHAGORAS: Jurnal Pendidikan Matematika, 14(1), 102-111. doi: https://doi.org/10.21831/pg.v14i1.22063 


\section{PENDAHULUAN}

Objek matematika sebagian besar bersifat abstrak dan sulit untuk dibayangkan sehingga banyak siswa yang kesulitan untuk memahaminya. Salah satu topik dalam matematika yang banyak mempelajari benda-benda abstrak yaitu geometri. Dalam pembelajaran geometri, siswa memerlukan abstraksi untuk menciptakan gambarangambaran secara mental untuk dianalisis atau bahkan dimanipulasi sehingga kemampuan berpikir geometri mereka berkembang. Dalam skema Van Hiele (1999), kemampuan siswa dalam melakukan hal ini terbagi menjadi 5 tingkatan yaitu 1) visualization, 2) analysis, 3) informal deductive, 4) formal deductive, dan 5) rigor. Dalam rangka membantu siswa untuk mencapai tingkatan rigor dalam pembelajaran geometri, tentunya diperlukan usaha-usaha untuk membantu siswa melakukan abstraksi-abstraksi sehingga objek geometri dapat dengan mudah diterima.

Salah satu solusi untuk mengatasi hal ini yaitu dengan menggunakan alat-alat Euclid seperti penggaris, jangka, dan busur untuk menggambar objek geometri di papan tulis atau whiteboard. Dengan menggambar langsung di papan tulis, objek-objek geometri dapat dengan mudah divisualisasikan kepada siswa. Metode ini dapat dikatakan yang paling populer dan sering dilakukan oleh guru maupun pendidik mulai dari zaman dahulu sampai era modern seperti sekarang. Salah satu alasannya yaitu karena alat-alat Euclid mudah digunakan dan lebih sederhana dibanding dengan teknologi komputer yang tentunya memerlukan kemampuan khusus dan waktu yang tidak sedikit seperti GCLC/WINGCLC (Janičić, 2006. 2010), DGS (Straesser, 2002), Geogebra (Majerek, 2014), Augmented Reality (Purnama, Andrew, \& Galinium, 2014) dan lain-lain. Namun, penggunaan alat-alat Euclid untuk menggambar terkadang tidak maksimal dikarenakan kurang efisien dan merepotkan. Sebagai contoh, seorang guru akan kesulitan jika harus berpindah-pindah ruangan sambil membawa peralatan yang begitu banyak dan memberatkan. Selain itu, guru juga sering kerepotan dalam menggunakan alat-alat ini karena harus memegang begitu banyak jenis alat sambil menjelaskan kepada siswa. Akibatnya, banyak guru yang kemudian justru menggambar objek geometri tanpa menggunakan alat-alat ini sehingga gambar yang seharusnya membantu siswa memahami materi, justru malah membuat mereka semakin tidak paham. Oleh karena itu, diperlukan suatu alat yang lebih efektif dan efisien untuk digunakan dalam kegiatan pembelajaran geometri.

Penggunaan penggaris, busur derajat dan kompas sejak zaman dahulu hingga sekarang tampaknya tidak ada masalah sama sekali. Sebagai bukti, tidak ada perkembangan signifikan pada alat dan tampilan mereka sebagian besar sama. Tidak ada fitur baru yang terlihat pada mereka. Perkembangan terakhir yaitu berupa penggaris yang juga bisa menjadi kompas dan busur derajat yang dibuat oleh Feldhake (1958), Woods (1985), dan Lin (2002). Mereka mengembangkan kombinasi penggaris, busur derajat dan kompas dengan membuat penggaris persegi panjang. Berbeda dengan sebelumnya, Henry (1926) dan Klemm (1951) mengembangkan kombinasi busur derajat dan kompas. Sementara itu, upaya menggabungkan penggaris dan busur derajat juga telah dilakukan oleh Heinz (1981), Ferris (1904), dan Johnson (2007). Namun, pengembangan semacam ini pada penggaris sebagian besar hanya untuk siswa, bukan untuk guru. Masalah guru dalam menggunakan alat-alat ini masih belum terpecahkan.

Salah satu alternatif untuk menyelesaikan permasalahan di atas yaitu dengan mengembangkan suatu alat yang menggabungkan alat-alat Euclid seperti penggaris, jangka, dan busur sehingga penggunaannya akan lebih efisien dan lebih fleksibel untuk dibawa berpindah-pindah ke mana pun. Oleh karena itu, penelitian ini bertujuan untuk menghasilkan alat ini yang dinamakan GeoKlik untuk mendukung kegiatan pembelajaran geometri. GeoKlik merupakan penggabungan alat-alat menggambar geometri Euclid yang didesain agar penggunaannya lebih fleksibel dan mudah sehingga guru maupun siswa dapat menggunakannya dalam proses belajar mengajar tanpa kesulitan. Dengan adanya alat ini, diharapkan kualitas pembelajaran geometri akan meningkat sehingga perkembangan kemampuan berpikir geometri siswa semakin lebih baik.

Alat pembelajaran merupakan suatu media yang telah didesain dan diproduksi dengan tujuan untuk mendukung proses pembelajaran (Adipurnomo, 2006). Menurut Falahudin (2014), alat pembelajaran atau alat bantu pembelajaran adalah alat yang digunakan oleh pembelajaran untuk mempermudah tugas dalam mengajar. Sehingga bisa disimpulkan bahwa alat pembelajaran adalah alat yang mendukung dan mempermudah proses belajar mengajar. Berdasarkan cakupannya, alat pembelajaran terbagi menjadi dua jenis yaitu 1 ) alat pembelajaran yang bersifat umum dan 2) alat pembelajaran yang bersifat khusus (Ibrahim \& Syaodih, 2003). Alat yang bersifat umum bisa digunakan untuk semua mata pelajaran contohnya penggaris, papan tulis dan lain-lain. Sedangkan alat yang bersifat khusus hanya digunakan untuk mata pelajaran tertentu saja contohnya mikroskop, busur, jangka, dan lain-lain. Peran alat pembelajaran cukup krusial dalam pelaksanaan pembelajaran, karena tanpa alat tersebut kegiatan pembelajaran tidak dapat berlangsung dengan baik. 
Menurut Adipurnomo (2006) media pembelajaran yang baik memenuhi kriteria sebagai berikut: 1) bersifat ekonomis, 2) bersifat praktis dan sederhana, 3) mudah diperoleh, 4) bersifat fleksibel, dan 5) komponen-komponennya sesuai dengan kompetensi. Alat pembelajaran dan media pembelajaran pada hakikatnya sama, yang membedakan hanyalah pada ada tidaknya kandungan pesan atau isi pelajaran. Pada alat pembelajaran tidak terkandung pesan atau isi pelajaran. Namun, alat pembelajaran memiliki peranan yang penting dalam membantu proses belajar mengajar. Sedangkan media pembelajaran selalu mengandung pesan atau isi pelajaran di dalamnya. Oleh karena itu, kriteria alat pembelajaran yang baik juga mengacu pada kriteria media pembelajaran. Berdasarkan kriteria di atas, dapat disimpulkan bahwa alat pembelajaran yang baik adalah: 1) bersifat ekonomis, 2) bersifat praktis dan sederhana, 3) mudah diperoleh, 4) bersifat fleksibel, dan 5) komponen-komponennya sesuai dengan fungsinya.

Dalam memahami konsep-konsep matematika yang abstrak khususnya konsep geometri, siswa memerlukan bantuan gambar untuk memudahkan visualisasi bangun-bangun geometri. Dalam pembelajaran geometri, penggunaan alat pembelajaran yang tepat diharapkan dapat meningkatkan motivasi belajar siswa. Hal ini sebagaimana penggunaan alat peraga sebagai bagian dari media pembelajaran yang juga dapat meningkatkan motivasi belajar siswa (Annisah, 2017). Begitu juga pemakaian media pembelajaran dalam proses belajar mengajar dapat membangkitkan minat dan keinginan yang baru, membangkitkan motivasi dan rangsangan kegiatan belajar, dan bahkan membawa pengaruh-pengaruh psikologis terhadap siswa (Falahudin, 2014).

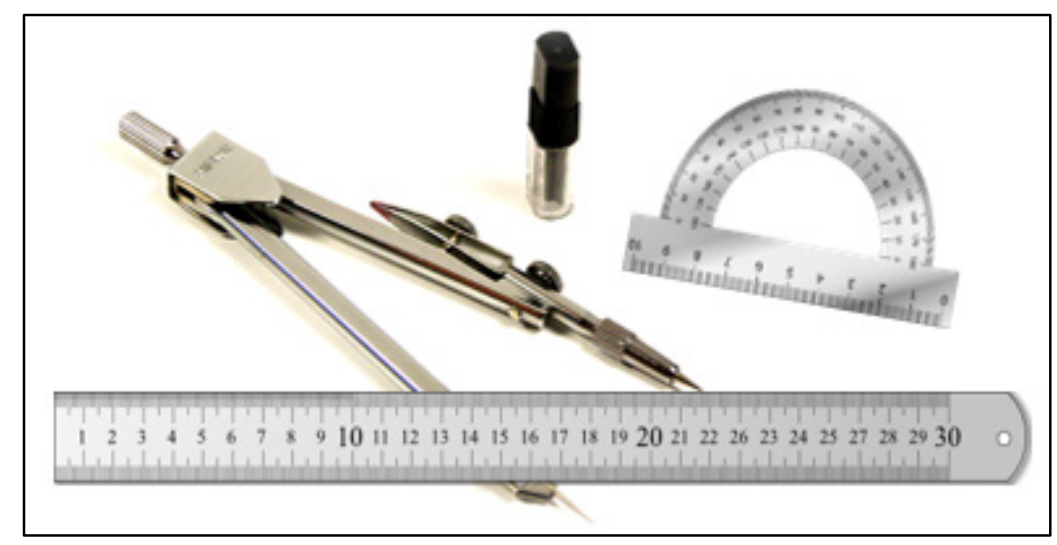

Gambar 1. Penggaris, Jangka, dan Busur

Alat-alat Euclid terdiri dari penggaris, busur, dan jangka yang sering digunakan untuk mengkonstruksi objekobjek geometri. Penggaris digunakan untuk mengukur panjang suatu benda atau menjadi acuan satuan panjang ketika menggambar (lihat Gambar 1). Sedangkan, busur digunakan untuk mengukur besar sudut. Salah satu contoh busur dapat dilihat pada Gambar 1. Berbeda dengan penggaris dan busur, jangka bukanlah suatu alat yang digunakan untuk mengukur. Tetapi, jangka merupakan alat yang berfungsi untuk menggambar objek melingkar atau melengkung seperti lingkaran. Jenis-jenis jangka saat ini ada banyak sekali mulai dari model yang menggunakan pensil maupun yang tidak. Alat-alat ini sangatlah penting terutama bagi mereka yang berkecimpung dalam dunia menggambar misalnya seperti seorang arsitek ataupun guru. Dalam perkembangannya ketiga alat ini tidak terlalu mendapat banyak perhatian seiring berkembangnya teknologi. Akibatnya bentuk dan rupanya tidak banyak mengalami perubahan yang berarti. Padahal teknologi yang semakin maju seharusnya pun ikut memberikan efek perkembangan pada alat-alat ini. Akibatnya, di saat alat-alat lain menjadi semakin praktis dan mudah digunakan seperti proyektor, smartboard, pointer, smartphone dan lain-lain, alat-alat Euclid menjadi terlihat tidak efisien dan ribet. Contohnya, seorang arsitek atau guru harus membawa begitu banyak peralatan untuk melakukan pekerjaannya karena alat-alat Euclid ini terpisah-pisah dan besar. Oleh karena itu, sudah saatnya alat-alat ini lebih dikembangkan agar menjadi semakin baik dan mudah untuk digunakan.

GeoKlik merupakan gabungan dari tiga jenis alat pembelajaran dalam geometri Euclid yaitu: 1) penggaris, 2) jangka, dan 3) busur. Nama GeoKlik sendiri terinspirasi dari istilah "Geometri Euclid" dengan tambahan "Klik" yang berarti pengguna bisa merubah fungsi alat misalnya dari penggaris menjadi jangka hanya dengan satu gerakan "Klik". Gambaran kasar desain alat GeoKlik yang akan dikembangkan dapat dilihat pada Gambar 2. GeoKlik diprediksi memiliki beberapa keunggulan dibanding alat-alat konvensional yang lain. Pertama, GeoKlik sudah 
disesuaikan untuk penggunaan baik pada whiteboard maupun pada papan biasa atau kertas. Ini berbeda dengan alat-alat konvensional yang kadang sulit digunakan karena tidak cocok dengan bidang gambar.

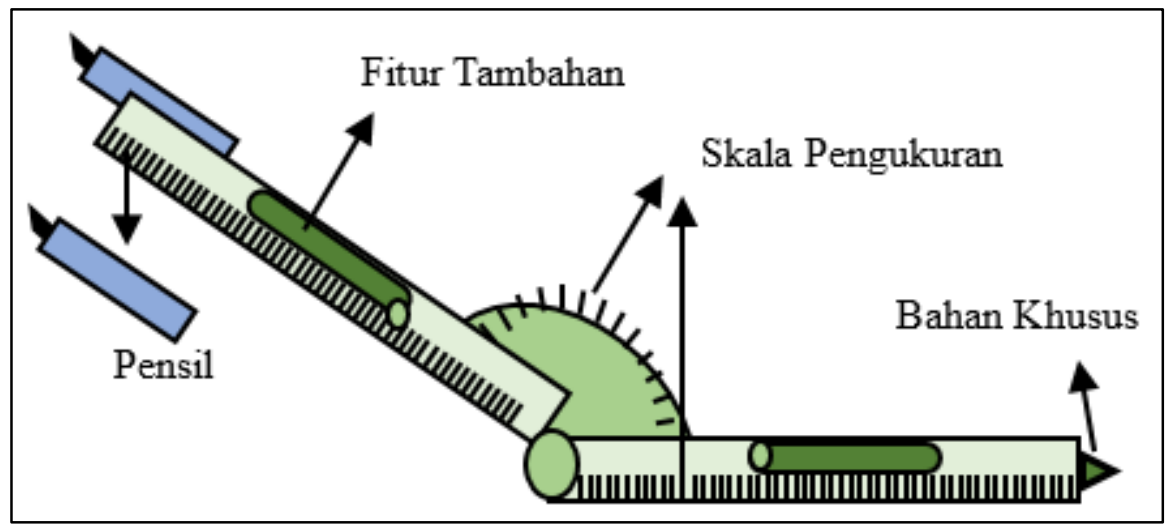

Gambar 2. Rancangan Awal Alat GeoKlik

Manfaat kedua GeoKlik yaitu pengguna tidak perlu berganti-ganti alat ketika menggambar dikarenakan fitur busur dan penggaris telah terintegrasi pada alat. Sebagai contoh, untuk menggambar sudut $60^{\circ}$ atau garis lingkaran dengan jari-jari $10 \mathrm{~cm}$, pengguna hanya perlu menyesuaikan skala pada GeoKlik sehingga garis yang dihasilkan otomatis akan memiliki ukuran yang diinginkan. Pada alat konvensional, hal ini tidak mungkin untuk dilakukan oleh pengguna karena alat-alat tidak terintegrasi. Manfaat ketiga GeoKlik yaitu mempermudah guru dalam kegiatan pembelajaran karena lebih efisien, praktis, dan fleksibel. Misalkan, seorang guru tidak dapat menjelaskan pada siswa sambil menggambar karena alat sulit digunakan. Jika guru menggunakan GeoKlik maka masalah seperti di atas akan terselesaikan. Selain manfaat-manfaat di atas, GeoKlik juga menawarkan fitur tambahan seperti alat untuk meniru atau memperbesar gambar, penggaris segitiga atau siku-siku dan masih banyak fitur yang mungkin ditambahkan dalam pengembangan GeoKlik.

Dari uraian yang telah dikemukakan sebelumnya, dapat dipahami bahwa pengembangan alat pembelajaran geometri penting dilakukan. Dengan demikian, penelitian ini bertujuan untuk menghasilkan alat pembelajaran matematika untuk mendukung kegiatan pembelajaran geometri. Selain itu, penelitian ini juga bermaksud untuk mendeskripsikan kualitas alat yang dikembangkan dilihat dari aspek desain, isi, dan respon pengguna.

\section{METODE}

Untuk mencapai tujuan yang telah diuraikan pada bagian pendahuluan, penelitian ini menggunakan metode penelitian pengembangan dengan model $4 \mathrm{D}$ yang terdiri dari 4 tahap pengembangan yaitu 1) define, 2) design, 3) develop, dan 4) disseminate (Thiagarajan, Semmel, \& Semmel, 1974; Bustang, 2010; Mulyatiningsih, 2011). Metode penelitian dipilih dengan menimbang tujuan penelitian dan jenis data yang akan diteliti. Adapun kegiatan-kegiatan yang dilakukan pada setiap tahap pengembangan yaitu sebagai berikut (Bustang, 2010):

Tahap pertama yaitu tahap define. Pada tahap ini dilakukan kegiatan analisis kebutuhan dalam pembelajaran geometri. Analisis kebutuhan bertujuan untuk menemukan desain alat yang diharapkan oleh guru dan siswa dalam pembelajaran geometri sehingga diperoleh kriteria-kriteria produk yang diinginkan dan dibutuhkan oleh siswa maupun guru.

Tahap kedua adalah tahap design. Pada tahap desain dilakukan penyusunan desain produk yang ingin dikembangkan. Desain ini meliputi bentuk, rancangan, dan bahan baku yang diperlukan. Pada tahap ini pula dikembangkan instrumen-instrumen penilaian terhadap produk seperti desain dan kepraktisannya.

Tahap ketiga yaitu tahap develop. Tahap ini terdiri dari dua bagian yaitu: pengembangan dan pengujian. Pengembangan dilakukan berdasarkan hasil dari tahap 1 dan 2. Sementara pengujian produk dilakukan setelah pengembangan pertama selesai. Pengujian dilakukan untuk mengetahui kualitas produk dan memperbaiki produk bila ditemukan ada bagian yang kurang tepat.

Tahap terakhir adalah tahap disseminate. Tahap diseminasi merupakan tahap penyebaran, publikasi, atau implementasi hasil produk yang telah melewati 3 tahap pengembangan sebelumnya. Adapun alur penelitian pengembangan dengan model 4D disajikan pada Gambar 3. 


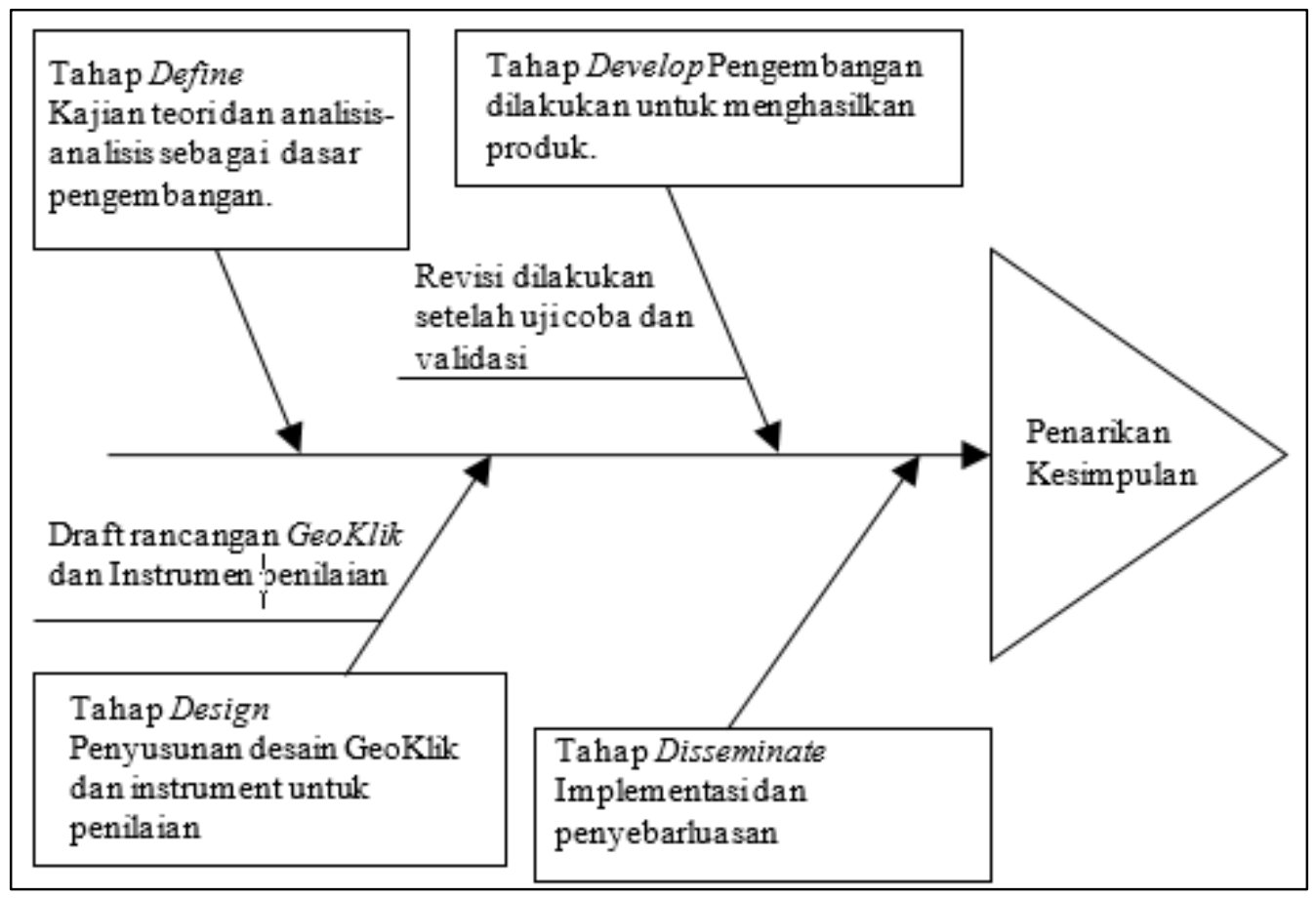

Gambar 3. Fishbone Diagram Alur Penelitian

Penelitian ini dilaksanakan di Program Studi Pendidikan Matematika, FKIP Kampus IV Universitas Ahmad Dahlan (UAD) yang beralamat di Jalan Ringroad Selatan, Tamanan, Banguntapan, Bantul, Yogyakarta. Subjek penelitian adalah mahasiswa dan guru dari sekolah yang bekerja sama dengan UAD serta beberapa validator. Adapun mahasiswa ada sebanyak 10 orang dari Program Studi pendidikan matematika UAD dan guru sebanyak 10 orang dari berbagai sekolah di Yogyakarta.

Adapun Ahli media yang menilai ada sebanyak dua orang yang merupakan dosen pendidikan matematika UAD dengan bidang keahlian geometri dan media. Teknik pengumpulan data dalam penelitian ini yaitu menggunakan lembar validasi produk, lembar respon siswa dan guru serta dokumentasi. Pada penelitian ini hanya menghasilkan produk melalui tahapan pengembangan yang telah ditentukan. Penelitian pengembangan tidak harus mengukur efektivitas produk melainkan lebih kepada penilaian kualitas produk bagaimana tahapan pengembangannya. Untuk mengukur efektivitas produk dalam pembelajaran maka perlu penelitian lebih lanjut.

Sedangkan teknik analisis data dalam penelitian ini menggunakan metode deskriptif kualitatif. Namun, analisis data tetap melibatkan data kuantitatif dan statistika sederhana. Data kuantitatif dianalisis dengan menggunakan teknik analisis deskriptif gabungan kuantitatif dan kualitatif untuk mengetahui kriteria kualitas alat pembelajaran yang dikembangkan. Adapun data yang diperoleh berupa data validasi dan respon siswa dan guru. Data lembar validasi dianalisis untuk mengetahui kualitas produk berdasarkan aspek yang diamati. Masing-masing aspek (desain, kepraktisan dan respon) dianalisis berdasarkan butir-butir pertanyaan terlebih dahulu. Setelah diperoleh kesimpulan, data kemudian dihitung secara keseluruhan dengan menjumlah total skor yang diperoleh dan kategorinya. Kriteria pengkategorian skor mengacu pada kriteria kualitas produk menurut Widoyoko (2017) sebagai mana disajikan pada Tabel 1.

Tabel 1. Kriteria Penilaian Produk

\begin{tabular}{lll}
\hline No. & Rerata Skor & Kriteria \\
\hline 1 & $X>4,2$ & Sangat Baik \\
2 & $3,4<X \leq 4,2$ & Baik \\
3 & $2,6<X \leq 3,4$ & Cukup \\
4 & $1,8<X \leq 2,6$ & Kurang \\
5 & $X \leq 1,8$ & Sangat Kurang \\
\hline
\end{tabular}

Data hasil dokumentasi digunakan sebagai data pendukung dalam penulisan laporan dari proses pengembangan sampai uji coba dan revisi produk akhir. Untuk menjamin validitas analisis data, peneliti melakukan 
member checking dan konsultasi dengan para ahli sehingga kesalahan interpretasi data dapat diminimalisir sekecil mungkin.

Hasil analisis data yang diperoleh dijadikan sebagai dasar untuk mengetahui kualitas alat pembelajaran GeoKlik yang dikembangkan. Alat Pembelajaran GeoKlik yang dikembangkan dikatakan layak untuk dijadikan sebagai alat pembelajaran matematika khususnya geometri jika skor rata-rata penilaian keseluruhan dari masingmasing ahli, yaitu ahli media dan ahli materi, serta respon guru dan siswa terhadap alat pembelajaran yang dikembangkan dalam kategori minimal baik.

\section{HASIL DAN PEMBAHASAN}

\section{Hasil Penelitian}

Hasil penelitian ini diuraikan sesuai tahapan penelitian pengembangan model 4D, yang meliputi tahap pendefinisian, desain, pengembangan, dan desiminasi. Adapun masing-masing tahapan tersebut diuraikan sebagai berikut.

\section{Tahap Define}

Pada tahap ini dilakukan beberapa kegiatan yaitu analisis kebutuhan yang melibatkan guru maupun siswa di Kota Yogyakarta. Total ada 44 responden yang mengisi kuesioner dengan rincian yaitu guru sebanyak 29 orang dan mahasiswa/siswa sebanyak 15 orang. Hasil survei menunjukkan bahwa $100 \%$ guru menggunakan penggaris dalam menggambar objek geometri, diikuti oleh $41,38 \%$ guru menggunakan busur serta $44,83 \%$ menggunakan jangka. Tiga alat ini merupakan tiga alat yang paling banyak digunakan oleh guru. Alat-alat tersebut $89,66 \%$ terbuat dari kayu, sedangkan dari bahan aluminium atau plastik masing-masing sebanyak $10,34 \%$. Hal ini menunjukkan bahwa alat dengan bahan kayu sangat diminati dalam pembelajaran. Walaupun alat ini sebagian besar tersedia di sekolahsekolah, tetapi hanya $68,97 \%$ yang benar-benar menggunakannya dalam menggambar objek geometri. Salah satu alasannya yaitu karena papan tulis yang licin mengingat lebih dari $90 \%$ sekolah menggunakan whiteboard di kelas. Tidak sedikit pula guru yang merasa kerepotan dengan penggunaan alat-alat ini yaitu sebanyak $44,83 \%$. Ada yang kesulitan karena alat terlalu besar, tidak praktis, ataupun penggunaan spidol yang tidak kompatibel. Oleh karena itu, $86,21 \%$ guru setuju jika ada alat pembelajaran geometri yang dapat berfungsi sebagai penggaris, jangka, dan busur sekaligus.

\section{Tahap Design}

Mempertimbangkan kebutuhan pengguna, memang sebagian besar mengalami kendala yaitu alat pembelajaran yang sekarang kurang praktis dan merepotkan. Penggunaan alat tersebut pada papan tulis yang terbuat dari bahan berbeda juga bermasalah karena sering terjadi ketidakcocokan antara alat dan permukaan. Untuk mengatasi permasalahan di atas maka kami mendesain suatu alat pembelajaran geometri atau pembelajaran matematika pada umumnya, yang dapat berfungsi sebagai penggaris, jangka, dan busur sekaligus. Pada tahap ini desain rancangan alat dilakukan beberapa kali. Rancangan yang pertama atau rancangan awal berupa alat dengan jangka sebagai bentuk utama dan busur sebagai skala pada bagian pangkal jangka. Apabila kedua kaki jangka direntangkan sampai $180^{\circ}$ maka akan membentuk penggaris. Desain lanjutan dilakukan melalui aplikasi Google SketchUp untuk membuat detail desain yang telah dirancang. Rancangan ini kemudian disempurnakan dengan mempertimbangkan kekurangan yang ditemukan pada saat mendesain GeoKlik tahap 2. Desain yang terakhir ini kemudian yang dikembangkan lebih jauh menjadi alat menggunakan bahan seperti kayu atau yang lainnya.

\section{Tahap Development}

Pada tahap pengembangan ini dilakukan beberapa sub tahapan pengembangan, yang pertama yaitu pengembangan prototype 1 dan GeoKlikv1. Pengembangan prototype 1 ini bertujuan merealisasikan desain tahap 2 GeoKlik, sehingga terlihat bentuknya dan untuk mencoba apakah alat bekerja dengan baik atau tidak. Prototype 1 ini dikembangkan dengan menggunakan bahan kertas karton setebal 3 milimeter dengan bantuan alat seperti cutter, gunting, lem kayu, lem cair, penggaris, pensil, busur, bor, amplas, dan masih banyak lainnya. Hasil dan proses pengembangan prototype 1 disajikan pada Gambar 4.

Setelah proses pembuatan prototype 1 ini, kemudian GeoKlik v1 dikembangkan oleh tukang kayu yang menjadi mitra peneliti. GeoKlik v1 ini dibuat berdasarkan prototype 1 yang diberikan kepada tukang kayu tersebut. Adapun bahan yang digunakan yaitu kayu Albasiah (Sengon). Pemilihan kayu Albasiah sebagai bahan dasar 
pembuatan alat pembelajaran GeoKlik dikarenakan jenis kayu tersebut memenuhi kriteria pembuatan bahan baku industri kreatif. Pandit, Nandika, \& Darmawan (2011) menyatakan bahwa sifat dasar kayu untuk bahan baku industri kreatif secara umum mempunyai karakteristik berasal dari pohon cepat tumbuh, ketersediaan dan harga relatif murah meski diameter kecil, lebih diinginkan kayu dengan berat jenis dan kerapatan rendah agar mudah proses pengerjaannya, stabilitas dimensi baik agar tidak mudah pecah, lebih disukai kayu berwarna putih atau terang agar mudah dalam finishing-nya dan kayu mempunyai tekstur halus karena sangat mempengaruhi kualitas produk yang dihasilkan. Adapun bahan seperti plastik atau aluminium tidak jadi digunakan karena keterbatasan alat dan tidak ada mitra yang bersedia. GeoKlik v1 ini memiliki spesifikasi yaitu: 1) terbuat dari bahan kayu, 2) ringan namun ringkih karena terlalu tipis dan kecil, 3) memiliki panjang kurang lebih $42 \mathrm{~cm}$ dengan tebal $2 \mathrm{~cm}, 4$ ) memiliki hand holder pada pangkal alat namun agak terlalu kecil, 5) hanya bisa menggunakan spidol ukuran kecil, spidol Snowman atau sejenisnya tidak bisa digunakan, 6) belum memiliki rancangan tumpuan untuk papan tulisnya, dan 7) belum memiliki skala pengukuran.

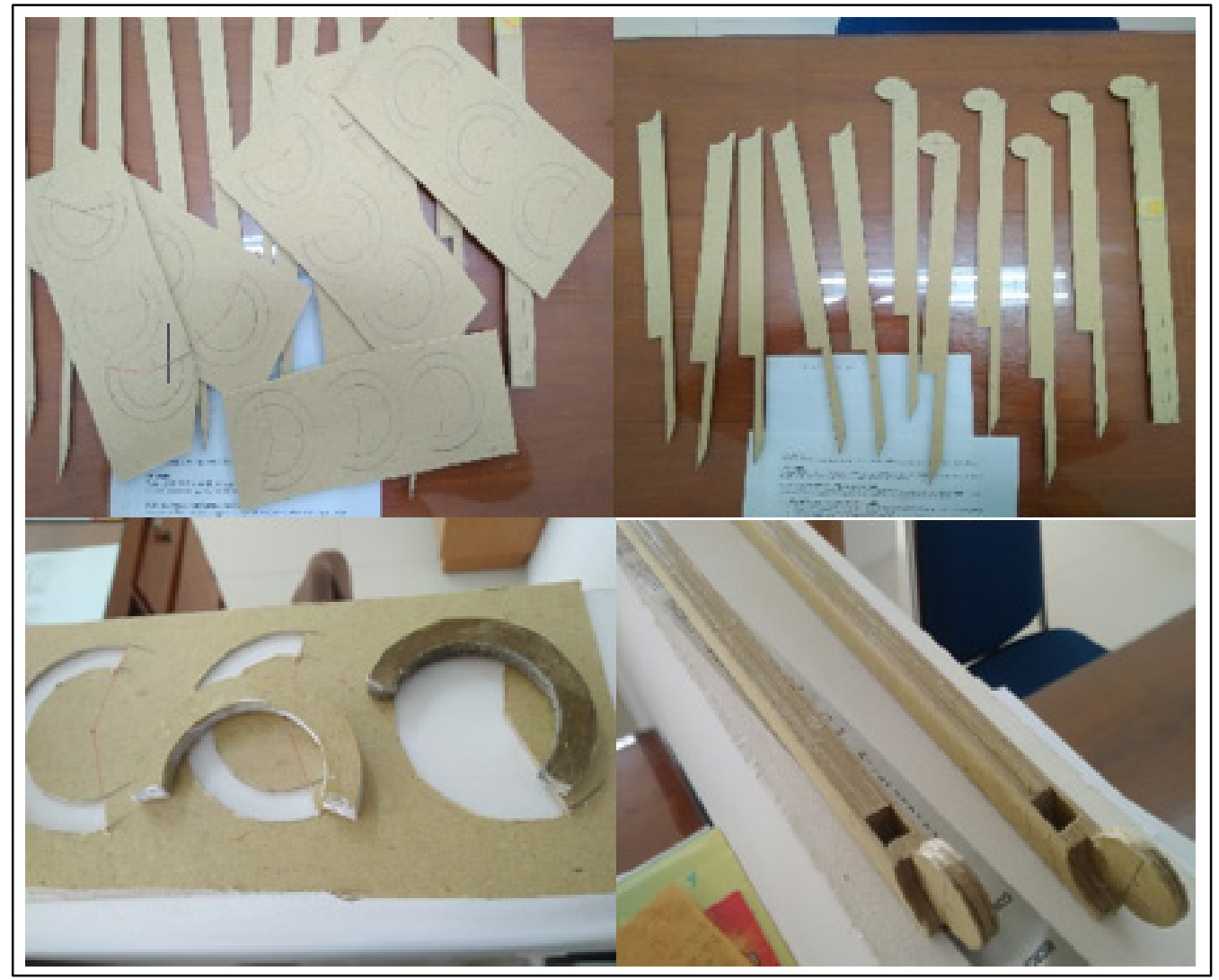

Gambar 4. Proses Pembuatan Prototype 1 GeoKlik Menggunakan Karton

Berdasarkan hasil pengembangan GeoKlik v1, ada beberapa aspek yang belum memenuhi kebutuhan pengguna yaitu seperti tidak bisa menggunakan spidol besar dan belum relevan dengan permukaan papan tulis. Oleh karena itu dikembangkan desain GeoKlikv2. Desain ini kemudian dicetak dan diproses oleh mitra menjadi alat GeoKlik v2. GeoKlik v2 ini memiliki spesifikasi yaitu: 1) terbuat dari bahan kayu, 2) agak berat namun kokoh, 3) memiliki panjang kurang lebih $42 \mathrm{~cm}$ dengan tebal $2,5 \mathrm{~cm}, 3)$ Holder cukup besar dan kuat dan terletak pada pangkal, 4) hanya bisa menggunakan spidol ukuran besar, spidol ukuran kecil belum bisa digunakan, 5) ada rancangan tumpuan, 6) belum memiliki skala pengukuran.

Hasil akhir dari pengembangan alat GeoKlik ini kemudian divalidasi oleh ahli media dengan aspek penilaian yaitu desain, keefektifan, dan kepraktisan. Selain itu, dilakukan penilaian melalui respon oleh guru dan siswa. Ada sebanyak 3 ahli media dengan bidang keahlian khusus yaitu geometri dan kependidikan. Untuk guru, ada sebanyak 4 guru serta 8 orang siswa yang memberikan penilaian. Pada tahap ini, diperoleh data bahwa rata-rata nilai validasi ahli media menunjukkan skor rata-rata keseluruhan yaitu sebesar 4,79. Dari aspek desain GeoKlik, diperoleh skor rata-rata sebesar 4,78. Aspek keefektifan GeoKlik memperoleh skor rata-rata 4,81. Sedangkan untuk aspek kepraktisan, GeoKlik mendapat nilai rata-rata 4,75. Meskipun skor yang diperoleh di atas 4,20, GeoKlik tetap 
mendapat masukan dari ahli untuk perbaikan sehingga alat menjadi lebih baik. Adapun masukan tersebut antara lain yaitu GeoKlik dimodifikasi lagi dengan bahan yang lebih ringan, kuat, dan mudah dioperasikan. Masukan lain yaitu perlu dikembangkan jangka yang sesuai aturan atau kaidah penggunaan jangka, untuk pengukuran panjang belum ada satuan milimeter, karena alat tebal diperlukan suatu skala yang sejajar atau sama, Box penyimpanan terlalu berat, dan pangkal titik untuk whiteboard kurang lancip dan tidak terlihat.

Sedangkan dari penilaian respon guru dan siswa diperoleh nilai respon rata-rata guru yaitu sebesar 4,79, sedangkan nilai respon rata-rata siswa yaitu sebesar 4,51. Nilai rata-rata terendah respon guru ada pada aspek keefektifan dengan skor 4,75. Sedangkan untuk respon siswa, skor rata-rata terendah ada pada aspek kepraktisan yaitu sebesar 4,47. Dari hasil penilaian respon ini diperoleh pula masukan-masukan untuk perbaikan alat pembelajaran GeoKlik agar lebih baik lagi. Beberapa masukan dari guru dan siswa tersebut yaitu: 1) tempat penyimpanannya harus lebih minimalis dan mudah dibawa; 2) lubang spidol dibuat lebih fleksibel agar bisa digunakan untuk kapur; 3) hendaknya menggunakan bahan kayu yang lebih ringan tetapi awet; dan 4) belum dapat digunakan untuk papan tulis kapur.

\section{Tahap Dissemination}

Untuk melakukan diseminasi produk ini, peneliti melakukan beberapa kegiatan untuk mengimplementasikan GeoKlik atau pun mensosialisasikannya. Pertama, GeoKlik digunakan dalam perkuliahan mata kuliah geometri dan analisis di Universitas Ahmad Dahlan. Pada kegiatan ini, GeoKlik digunakan sebagai alat menggambar objek-objek geometri pada proses penyampaian materi. Selain implementasi, GeoKlik juga disosialisasikan kepada guru di sekolah-sekolah SMP Muhammadiyah Kota Yogyakarta sebagai bagian dari kegiatan pengabdian kepada masyarakat. GeoKlik dijadikan sebagai teknologi baru dalam menggambar objek geometri. Selain sosialisasi dan implementasi, GeoKlik dipublikasikan melalui seminar-seminar, baik nasional maupun internasional. GeoKlik saat ini juga dalam proses pengajuan paten sederhana sehingga dapat diproduksi secara masal.

\section{Pembahasan}

Berdasarkan paparan hasil penelitian pengembangan alat pembelajaran GeoKlik dengan model pengembangan 4D, dapat ditunjukkan bahwa hasil validasi ahli media terhadap GeoKlik dapat dikatakan sangat baik dengan skor rata-rata 4,79. Nilai terendah yaitu 4,33 pada bagian buku manual dan skala pengukuran saja. Secara keseluruhan ada 4 orang guru dan 8 orang siswa yang memberikan penilaian terhadap alat GeoKlik ini. Dari data yang diperoleh didapatkan nilai respon rata-rata guru yaitu sebesar 4,79 sedangkan nilai respon rata-rata siswa yaitu sebesar 4,51. Keduanya masuk dalam kategori sangat baik. Nilai rata-rata terendah respon guru ada pada aspek keefektifan dengan skor 4,75 tetapi masih masuk ke dalam kategori sangat baik. Sedangkan untuk respon siswa, skor rata-rata terendah ada pada aspek kepraktisan yaitu sebesar 4,47 dengan kategori sangat baik. Keseluruhan penilaian alat pembelajaran GeoKlik baik dari ahli media, guru maupun siswa masuk dalam kategori sangat baik dengan skor di atas 4,20.

Dari hasil pengembangan alat pembelajaran GeoKlik diperoleh penilaian dari ahli media, guru, maupun siswa dengan kategori sangat baik. Hal ini menunjukkan bahwa GeoKlik sangat layak digunakan dalam pembelajaran matematika di kelas, khususnya materi geometri. Penggunaan alat pembelajaran GeoKlik dalam menggambar bangun-bangun geometri di papan tulis akan membantu guru memvisualisasikan objek-objek Geometri sehingga dapat berkontribusi pada salah satu proses kognitif yang terlibat dalam aktivitas geometri yang berupa proses konstruksi konsep-konsep geometri pada diri siswa dengan bantuan alat (Laborde, Knigos, Hollebrands, \& Strässer, 2006). Alat pembelajaran GeoKlik ini juga akan menambah referensi alat pembelajaran matematika kontemporer yang bisa digunakan baik oleh guru, dosen, siswa ataupun mahasiswa.

Sebagai alat pembelajaran matematika yang kontemporer, GeoKlik memiliki pangsa pasar yang baik. Oleh karena itu perlu disusun strategi pemasaran yang baik agar hasil pengembangan alat pembelajaran ini dapat terdiseminasikan ke guru-guru atau sekolah-sekolah baik jenjang SD, SMP, SMA atau SMK, dan bahkan sampai di tingkat Perguruan Tinggi. Salah satu strategi pemasaran GeoKlik yang bisa dilakukan adalah dengan mensosialisasikan GeoKlik pada kegiatan penelitian dan pengabdian dosen di sekolah-sekolah dengan peserta adalah guru, baik guru SD, SMP, maupun SMA. Serta pada kegiatan seminar baik nasional maupun internasional. GeoKlik juga dijadikan sebagai unit bisnis Program Studi Pendidikan Matematika UAD untuk mendukung pengembangan laboratorium program studi pada bidang pengembangan unit bisnis berbasis keilmuan pada Program Studi Pendidikan Matematika yang bergerak pada penyediaan alat peraga ke sekolah-sekolah (Istiandaru, Istihapsari, \& 
Fitriyani, 2017). Dalam hal ini, tentu alat pembelajaran GeoKlik mengambil peran yang cukup besar dan diharapkan dapat berkontribusi maksimal bagi kemajuan pendidikan di Indonesia.

\section{SIMPULAN}

Kesimpulan yang diperoleh pada dari penelitian ini yaitu bahwa prosedur pengembangan alat GeoKlik ini mencakup empat tahapan yaitu define, design, development, dan dissemination. Pada tahap define diperoleh data bahwa sebagian besar guru mengalami kesulitan menggunakan alat yang ada karena ketidaksesuaian teknologi dengan kondisi yang ada di sekolah, serta karena alat pembelajaran geometri saat ini kurang praktis. Pada tahap design dikembangkan dua prototype desain GeoKlik dengan kelebihan dan kekurangan masing-masing. Design yang dibuat secara umum memiliki spesifikasi yaitu GeoKlik memiliki bentuk dasar jangka, namun jika dilipat $180^{\circ}$ akan membentuk penggaris, dan pada poros alat terdapat skala derajat untuk mengukur besar sudut. Tahap development merupakan tahap pengembangan GeoKlik menggunakan bahan dasar kayu. Pada tahap ini dihasilkan alat GeoKlik yang dilengkapi dengan kotak penyimpanan, buku manual, dan dua jenis poros untuk whiteboard atau blackboard. Pada tahap dissemination, GeoKlik disosialisasikan melalui kegiatan pengabdian pada masyarakat serta melalui seminar, baik nasional maupun internasional.

GeoKlik divalidasi oleh dua orang ahli media dan juga oleh guru dan siswa. Dari aspek kualitas, alat GeoKlik mendapat penilaian sangat baik dari ahli media dengan nilai rata-rata 4,79. Dari aspek desain, GeoKlik mendapat nilai rata-rata sebesar 4,78 dengan kategori sangat baik. Aspek keefektifan GeoKlik juga memperoleh skor sangat baik dengan nilai rata-rata 4,81. Sedangkan untuk aspek kepraktisan, GeoKlik mendapat nilai rata-rata 4,75 dengan kategori sangat baik. Respon yang diberikan guru dan siswa terhadap alat GeoKlik ini juga sangat positif dengan nilai rata-rata keseluruhan yaitu 4,79 untuk respon guru, sedangkan nilai respon rata-rata siswa yaitu sebesar 4,51. Oleh karena itu, GeoKlik sangat layak digunakan oleh siswa, guru, mahasiswa, dosen, ataupun praktisi pendidikan. GeoKlik pun memiliki nilai jual yang tinggi bagi dunia pendidikan dalam upaya membantu guru menyelenggarakan pembelajaran geometri di kelas. Dengan penggunaan GeoKlik, bangun-bangun geometri dapat tervisualisasikan dengan baik, sehingga akan mudah dipahami siswa.

\section{UCAPAN TERIMA KASIH}

Ucapan terima kasih kepada Direktorat Riset dan Pengabdian Masyarakat (DRPM) Kemenristekdikti. Penelitian ini terlaksana atas pembiayaan dari Hibah Penelitian Dosen Pemula (PDP) dari DRPM Kemenristekdikti tahun anggaran 2018.

\section{DAFTAR PUSTAKA}

Adipurnomo, H. (2006). Sumber dan media pembelajaran. Malang: Pusat Pengembangan Penataran Guru IPS dan PMP Malang.

Annisah, S. (2017). Alat peraga pembelajaran matematika. Tarbawiyah Jurnal IImiah Pendidikan, 11(01), 1-15. Retrieved from http://e-journal.metrouniv.ac.id/index.php/tarbawiyah/article/view/356

Bustang, B. (2010). Pengembangan perangkat pembelajaran matematika berbahasa inggris berbasis realistik pada SMP rintisan sekolah bertaraf internasional (Skripsi tidak diterbitkan). Universitas Negeri Makassar, Makassar.

Falahudin, I. (2014). Pemanfaatan Media dalam Pembelajaran. Jurnal Lingkar Widya Iswara, 1(4), 10-117. Retrieved from https://juliwi.com/published/E0104/Paper0104_104-117.pdf

Feldhake, H. J. (1958). U.S. Patent No. 2,857,674. Washington, DC: U.S. Patent and Trademark Office.

Ferris, W. H. (1904). U.S. Patent No. 776,897. Washington, DC: U.S. Patent and Trademark Office.

Heinz, R. A. (1981). U.S. Patent No. 4,267,638. Washington, DC: U.S. Patent and Trademark Office.

Henry, T. (1926). U.S. Patent No. 1,576,800. Washington, DC: U.S. Patent and Trademark Office.

Ibrahim, M., \& Syaodih, N. (2003). Perencanaan pengajaran. Jakarta: Rineka Cipta

Istiandaru, A., Istihapsari, V., \& Fitriyani, H. (2017). studi kasus kualitas laboratorium pengembangan media pembelajaran matematika. Jurnal Pendidikan Matematika RAFA, 3(2), 214-222. doi: https://doi.org/10.19109/jpmrafa.v3i2.1743 
Janičić, P. (2006). GCLC - A tool for constructive euclidean geometry and more than that. In Iglesias A., \& Takayama N. (eds). Mathematical Software - ICMS 2006. Lecture Notes in Computer Science (vol. 4151, pp.58-73). Berlin: Springer. doi: https://doi.org/10.1007/11832225_6

Janičić, P. (2010). Geometry constructions language. Journal of Automated Reasoning, 44(1), 3-24. doi: https://doi.org/10.1007/s10817-009-9135-8

Johnson, M. (2007). U.S. Patent No. 7,188,427. Washington, DC: U.S. Patent and Trademark Office.

Klemm, W. F. (1951). U.S. Patent No. 2,542,537. Washington, DC: U.S. Patent and Trademark Office.

Laborde, C., Knigos, C., Hollebrands, K., \& Strässer, R. (2006). Teaching and learning geometry with technology. In Á. Gutiérrez \& P. Boero (Eds.). Handbook of research on the psychology of mathematics education: Past, present and future (pp. 275-304). Rotterdam: Sense Publisher. Retrieved from https://www.sensepublishers.com/media/457-handbook-of-research-on-the-psychology-ofmathematics-educationa.pdf

Lin, F. C. (2002). U.S. Patent No. 6,457,247. Washington, DC: U.S. Patent and Trademark Office.

Majerek, D. (2014). Application of Geogebra for teaching mathematics. Advances in Science and Technology Research Journal, 8(24), 51-54. doi: https://doi.org/10.12913/22998624/567

Mulyatiningsih, E. (2011). Pengembangan model pembelajaran. Retrieved from http://staffnew.uny.ac.id/upload/ 131808329/pengabdian/7cpengembangan-model-pembelajaran.pdf

Pandit, I. K., Nandika, D., \& Darmawan, I. W. (2011). Analisis sifat dasar kayu hasil hutan tanaman rakyat. Jurnal Ilmu Pertanian Indonesia, 16(2), 119-124. Retrieved from https://journal.jpb.ac.id/index.php/IIPI/article/view/6609

Purnama, J., Andrew, D., \& Galinium, M. (2014). Geometry learning tool for elementary school using augmented reality. Proceeding of 2014 International Conference on Industrial Automation, Information and Communications Technology (pp. 145-148). IEEE.

Straesser, R. (2002). Cabri-Geometre: Does dynamic geometry software (DGS) change geometry and its teaching and learning? International Journal of Computers for Mathematical Learning, 6(3), 319-333. doi: https://doi.org/10.1023/A:1013361712895

Thiagarajan, S., Semmel, D. S., \& Semmel, M. I. (1974). Instructional development for training teachers of exceptional children: A sourcebook. Minneapolis, MN: Indiana University Bloomington.

Van Hiele, P. (1999). Developing geometric thinking through activities that begin with play. Teaching Children Mathematics, 5(6), 310-316.

Widoyoko, S. E. P. (2017). Evaluasi program pembelajaran. Yogyakarta: Pustaka Pelajar.

Woods, W. D., \& Pigman, J. H. (1985). U.S. Patent No. 4,490,921. Washington, DC: U.S. Patent and Trademark Office. 